\title{
A pré-história do coro teatral na iconografia do kômos
}

\author{
ADRIANE DA SILVA DUARTE \\ Departamento de Letras Clássicas e Vernáculas \\ Faculdade de Filosofia, Letras e Ciências Humanas \\ Universidade de São Paulo
}

\begin{abstract}
RESUMO: Através da iconografia do kômos, é possível remontar à origem do coro grego, elemento central e característico do teatro clássico. Partindo da definição do kômos como "um grupo que se desloca para realizar uma ação cultual, com procissão e dança", examinaremos três aspectos de sua representação na arte cerâmica: mitológico, cultual e animal.
\end{abstract}

PALAVRAS-CHAVE: Teatro grego, Coro dramático, Iconografia dos kômoi, Religião grega, Dioniso.

Quem quer que se debruce sobre o teatro grego se perguntará sobre a origem de seu coro. Elemento central tanto da tragédia quanto da comédia e do drama satírico, esse grupo de bailarinos que também canta e dialoga com os atores confere ao drama grego clássico um lugar único na história do teatro. No entanto, aquele que se sentir atraído por essa questóo esbarrará na escassez de registros escritos que documentem a pré-história do coro dramático. Nesse caso a representação figurada fornecerá um testemunho imprescindível na recuperação dessa trajetória. Sem a pretensão de responder uma questão tão complexa, passarei a seguir ao exame das possibilidades que se abrem quando imagem e palavra vão lado a lado.

Adrados (Adrados, 1983, p.609) define o kômos como "un coro que se desplaza para realizar una acción cultual, con procesión y danza". Por uma questão de clareza, talvez fosse melhor substituir a palavra coro, muito especializada, por uma mais neutra, como grupo. O coro associa-se diretamente às representaçðes dramáticas, em cujo núcleo encontra-se. Formado por doze ou quinze participantes na tragédia e vinte e quatro na comédia, o coro é o elemento característico do teatro clássico ateniense. Tal como ocorre com o kômos, seus integrantes também dançam e cantam, relação explicitada na etimologia da palavra: chorós/choreîa, dança. Mas guardadas as semelhanças, o coro está mais restrito aos espetáculos dramáticos e líricos. $\mathrm{O}$ kômos antecede-o e o ultrapassa, já que nele reside a célula embrionária do coro, tanto no que diz respeito à comédia, cujo nome fornece, quanto à tragédia e ao ditirambo.

Voltando à definição de Adrados, sugiro que chamemos kômos "um grupo que se desloca para realizar uma ação cultual, com procissão e dança". Um cortejo, segundo Paulette GhironBistagne (Ghiron-Bistagne, 1976, p.208), composto de pessoas "mais ou menos embriagadas, que vão em desordem pelas ruas, cantando e dançando". 


\section{Adriane da Silva Duarte: A pré-história do coro teatral na iconografia do kômos.}

Em contraste com a pompé, procissão solene, formada por fiéis ordeiros que respeitosamente se dirigem ao local do culto para lá depositar oferendas ou sacrificar em honra a determinado deus, o kômos tem um caráter marcadamente não-oficial e popular, avesso a normas e aberto a improvisaçðes. Ambas as manifestaçðes, pompé e kômos, integram a festa e podem mesmo darse simultaneamente, mas enquanto a pompé esgota-se no trajeto de ida ao templo, o kômos vive seu ápice na volta, quando os participantes retornam às suas casas após o banquete ritual, obrigaçðes cumpridas, e entregues à celebração do feriado. Já que na Grécia não há fronteira clara entre o sagrado e o profano, os festivais eram uma oportunidade de lazer, proporcionando a suspensão da rotina.

Nesse contexto, o kômos está mais próximo dos desfiles carnavalescos, mas ao lado da folia preserva um sentido religioso. A embriaguez na Grécia antiga tem caráter sagrado, ligandose ao culto do deus Dioniso, a quem os gregos atribuem o dom do vinho aos mortais. Assim, kômos também pode ser entendido como uma festa em honra a Dioniso, acepção tão comum que se encontra no Dicionário Bailly, por exemplo. Origina-se aí o vínculo do deus com os participantes de um banquete, que são os komastaí.

$\mathrm{O}$ kômos surge na cerâmica ática dos séculos VI e $\mathrm{V}$ a.C. associado à figura de Dioniso. Não por coincidência, é também nesse período que se dá a oficialização dos espetáculos teatrais em Atenas, quando o arconte concede aos poetas coros às expensas da cidade. Durante o quinto século, a cidade se destaca no cenário cultural da Hélade por seus festivais dramáticos, notadamente pelas Grandes Dionísias, que são patrocinados pelo deus do vinho.

Para facilitar a análise dos tópicos de interesse para o estudo do coro, examinarei três aspectos da representação do kômos na arte cerâmica: o kômos mitológico, o kômos cultual e o kômos de disfarce animal.

O kômos mitológico é composto basicamente pelos companheiros de Dioniso na mitologia, os Sátiros e as Mênades ou Ninfas. Os primeiros são seres híbridos, meio homem e meio cavalo (à diferença dos centauros, são bípedes, possuem orelhas, cascos traseiros e rabos equinos, sendo no mais humanos), e as últimas são entidades femininas, por vezes de caráter sobrenatural, que acompanham o deus.

A ligação entre o deus e os Sátiros depende mais da tradição iconográfica do que da literária, uma vez que não há menção a ela nem em Homero, onde os Sátiros vinculam-se a Hermes, nem na grande obra consagrada a Dioniso que é As Bacantes de Eurípides. Na literatura, o convívio entre o deus e os Sátiros está restrito ao drama satírico, onde, no entanto, é corriqueiro. N'O Ciclope (v.01-09 e 65-75), também de autoria de Eurípides, Sileno, o pai dos Sátiros, declara ser companheiro de Dioniso desde a Gigantomaquia, quando lutaram lado a lado, e o coro lamenta que o cativeiro afaste-os das bacantes e do vinho novo.

Não é difícil imaginar a origem desse companheirismo, uma vez que os Sátiros, como seus parentes Centauros, caracterizam-se por um grande apetite sexual e por um fraco pela bebida. Seriam, portanto, atraídos pelo deus do vinho e da natureza selvagem, deus também do falo ereto, propiciador da fertilidade, e assim formariam seu cortejo barulhento.

Jeanmaire (Jeanmaire, 1985, p.278ss.) indica outras razðes que fariam dos Sátiros seguidores de Dioniso. Através do exame da idéia que os gregos tinham do cavalo como animal possuído e da sua participação em ritos fúnebres, ele conclui que os Sátiros pertencem ao mundo dos mortos, no qual Dioniso circula com certa familiaridade, como atesta o festival das Antestérias. Os Sátiros, enquanto demônios equinos, são seres adequados para comporem o cortejo sobrenatural do deus.

O kômos mitológico é bem retratado nas representaçðes do retorno de Hefesto, episódio em que Dioniso e os Sátiros escoltam o deus artesão ao Olimpo, de onde fora arremessado por Hera, sua mãe. Por vingança, Hefesto teria aprisionado a deusa num trono por ele construído. Os deuses, então, encarregam Dioniso de conduzir Hefesto de volta, já que somente ele seria capaz 
de libertar Hera. Embriagado, Hefesto chega montado num cavalo e cercado pelos barulhentos Sátiros. Não há registro literário desse mito que, no entanto, é bastante conhecido através da arte cerâmica.

A figura 1 apresenta um dos frisos do Vaso François (575 a.C.) em que é representado o retorno de Hefesto. Dioniso, numa de suas primeiras apariçðes na cerâmica, está à frente do cavalo que leva Hefesto ao Olimpo. O cortejo encerra-se por Sátiros, denominados Silenó, e Mênades (ao menos uma é visível no canto direito) que dançam ao som da flauta tocada por um deles. Tanto o cavalo quanto os Sátiros estão em ereção, certamente por estarem sob a influência de Dioniso. Hefesto traz nas mãos um copo em formato de chifre, indício do papel do vinho nesse episódio. Dioniso, que só tem visível a parte superior do corpo, apresenta barba bastante hirsuta (tão pontuda quanto a dos Silenos) e está coroado com a hera. Do lado oposto do vaso, alinhamse os deuses olímpicos, que recepcionam os recém-chegados. Em destaque, no centro, Hera atada ao seu trono.

Numa ânfora ática de meados do séc. VI a.C., figura 2, vê-se retratado o mesmo episódio. Hefesto, figura central em uma das faces do vaso, aparece novamente montado em um cavalo e cercado por um kômos misto, à direita Sátiros, que já apresentam traços mais humanos (notar os pés no lugar de cascos), à esquerda homens que dançam. Dioniso ocupa o outro lado da ânfora, onde, ao lado de uma mulher que porta coroas (Ariadne?), obtém vinho a partir das uvas.

Na cratera de Lydos, figura 3, também contemporânea à analisada anteriormente, o kômos é mais numeroso e animado. Os deuses não ocupam mais o lugar de honra: Hefesto some em cima do cavalo e Dioniso sequer é retratado. O destaque cabe ao Sátiro à esquerda do cavalo que, desenhado de frente, contrasta com os demais celebrantes que estão de perfil ${ }^{\prime}$. Os movimentos de braços e pernas sugerem passos de uma dança. $\mathrm{O}$ vinho está representado nos ramos de uva que os Sátiros carregam e no chifre que Hefesto segura. As mênades trazem a coroa de hera e a pele de corça, atributos característicos dos seguidores de Dioniso.

O fato de implicar num mito, torna a representação do kômos mitológico próxima da de um drama satírico ou mesmo da de uma tragédia, como As Bacantes, por exemplo. Facilmente podemos imaginar uma peça que desenvolva tal enredo ou outro assemelhado, concretizando assim a passagem do kômos para o coro teatral.

A crescente humanização na retratação dos kômoi leva à substituição dos Sátiros, que tiveram gradualmente suas características eqüinas atenuadas ${ }^{2}$, por mortais, que passam a compor preferencialmente o cortejo de Dioniso. Tais cenas provavelmente registram kômoi cultuais, com seus integrantes que cantam e dançam. Quando o deus está presente entre eles nada faz supor o registro de uma epifania, antes parece tratar-se da representação de sua estátua, adorada pelos fiéis. Um exemplo disso pode ser encontrado na ânfora de Amasis, da metade do séc. VI (figura 4), em que vemos um Dioniso rígido cercado por bacantes que dançam animadamente ao seu redor.

Em outros casos, quando há duplicação da figura normalmente associada ao deus, podese pensar que, ao invés de uma imagem divina, trata-se de seus seguidores, caracterizados como ele. É o caso da figura 5, um fundo decorado de uma taça de Siana datada do séc. VI, onde dois Dionisos estão diante um do outro. Ambos trazem os atributos do deus: a barba longa, o manto comprido, a coroa de hera e a taça de chifre. Embora o mito justifique a interpretação da cena como a do deus e seu duplo, afinal Dioniso nasceu duas vezes, também é possível julgar que se retrata não o deus, mas seguidores seus, identificados com ele através da imitação de seus atributos. Um exemplo de caracterização mimética desse tipo é dado n'As Bacantes, quando Tirésias e Cadmo preparam-se para cultuar Baco nas montanhas (v.174-177).

Por fim, não se pode deixar de mencionar os pintores do grupo komastés, do início do séc. VI a.C., que sofreram influência de modelos coríntios na sua representação de animados kômoi. Ao contrário do que ocorre com outros pintores, já não há mais uma imagem que possa ser 
identificada com Dioniso e o que surge em primeiro plano são os komastaí, como está visto na figura 6.

De grande significado para a investigação dos estágios anteriores do coro cômico são os kômoi de disfarce animal, já que é bastante recorrente a formação de coros caracterizados como animais na comédia antiga, conforme atestam os títulos de várias peças. Considerando somente a obra de Aristófanes que chegou até nós, são quatro as comédias que têm coro animal: $O s$ Cavaleiros, As Vespas, As Aves e As Rãs.

A função desse disfarce é motivo de controvérsia entre os helenistas. As primeiras tentativas de interpretação consideravam os kômoi animais como vestígios da existência de divindades teriomórficas na Grécia (Cook, apud Sifakis, 1971, p.79). Mas como observa Burkert (Burkert, 1990, p.65), embora os deuses gregos possam se metamorfosear e freqüentemente sejam associados a determinados animais, jamais houve propriamente culto a animais na Grécia, ao menos no mesmo sentido em que existiu no Egito, por exemplo.

Outros autores, entre os quais estão Gelzer e Meuli (apud Sifakis, 1971, p.79-80), acreditam que o kômos animal relaciona-se antes aos espíritos ancestrais, promotores da fertilidade. Desse prisma, o vínculo com Dioniso pode ser buscado na faceta infernal do deus. Jeanmaire (Jeanmaire, 1985, p.268-69) frisa bem o aspecto ctônico do mito e do culto de Dioniso, decorrente de seu papel enquanto divindade agrária. Identificado com a vinha, seu dom aos mortais, o deus está condenado ao desaparecimento cíclico a cada inverno, associado à morte, que encontra expressão em seu mito na narrativa do esquartejamento do primeiro Dioniso pelos Titãs. Além disso, há a consciência da parte dos gregos que a fertilidade da terra é garantida pelos mortos, sua riqueza. Os mortos fecundam a terra e asseguram o sucesso das colheitas. O festival das Antestérias reúne essas características do deus, o que ressurge na primavera e é celebrado com a abertura dos tonéis de vinho novo, associado ao sangue, à vida, e o que promove a volta dos espíritos ancestrais.

Segundo Ghiron-Bistagne (Ghiron-Bistagne, 1976, p.250), a dança do kômos animal teria aspecto propiciatório, exercendo influência mágica sobre a caça. Dioniso, tanto quanto divindade infernal quanto como agrária, participaria naturalmente desse cenário. Nesse sentido é esclarecedora a aproximação entre o deus e Ârtemis levada a cabo por Jeanmaire (Jeanmaire, 1985, p.270-272), em que ambos os deuses primitivamente seriam os condutores da caça selvagem, levando a morte com suas setas aos animais e aos homens. Um dos epítetos do deus em As Bacantes é ánax agreús, senhor caçador (v.1192), que ecoa o nome Zagreu, o primeiro Dioniso. Mais tarde teria havido uma especialização e Dioniso-Zagreu, também associado a Hades, o senhor dos mortos, seria vinculado ao mundo infernal. Mas ele jamais perderia de todo a faceta de caçador, haja visto a importância e a recorrência das imagens de caçada na tragédia de Eurípides, em que Penteu torna-se presa das Mênades, conduzidas pelo deus.

Na cerâmica, Dioniso aparece associado à caça numa taça de Siana do pintor de Heidelberg (550-530 a.C.), figura 7. O deus é visto dançando em meio a um grupo de jovens caçadores, caracterizados pela presença das lanças e do cachorro. A dança visaria à propiciação de uma caça abundante.

O disfarce animal pode ser entendido também como uma tentativa mágica de reparação pelo sangue derramado. Burkert (Burkert, 1990, p.58) explica a deposição dos ossos ou da pele do animal sacrificado sobre o altar como um modo de reavivar a vítima degolada. A relação do sacrificador em vista do sacrificado implica em um remorso, que remonta à angústia do caçador condenado a matar sua fonte de sustento e, depois, à do pastor que deve se alimentar de animais criados no âmbito de seu ô̂kos, quase parte de sua família. Tal sentimento subsiste até hoje nas zonas rurais, como atesta o artigo de Leach (Leach, 1983) sobre os tabus alimentares e linguísticos e os animais domésticos. Segundo ele o mal-estar é maior com relação ao porco, que além de ser criado com o único intuito de ser morto, habita muitas vezes o quintal e é alimentado com os 
restos de comida da cozinha. Assim, conclui o antropólogo (Leach, 1983, p.190), "matar e comer tais sócios comensais é, sem dúvida, um sacrilégio", sendo que a vergonha que sentimos desse ato é rapidamente associada ao animal em si.

Essa vergonha também pode ser expiada através da assimilação entre a caça e o caçador ou entre o sacrificador e a vítima. Por essa razão, informa Burkert (Burkert, 1990, p.65), certos sacerdotes usam atributos dos animais sacrificados, trata-se de uma forma de restituir a vida que eles mesmos findaram. Assim, o kômos animal esconderia uma maneira de purgar a culpa pelo derramamento de sangue através da ressurreição mágica da presa e, ao mesmo tempo, buscaria assegurar a abundância de alimento.

Dando um salto, mas seguindo o mesmo raciocínio, Burkert (Burkert, 1990, p.65) especula que é natural que, nos festivais teatrais de Atenas, o drama satírico, que traz à cena um coro semianimal e de natureza sobrenatural, seja precedido pela tragédia, a celebração do sacrifício. Após o canto do bode, tragoidía, os bodes materializar-se-iam no palco. E ainda se poderia ir mais longe, acrescentando que a comédia, que encerra o dia de apresentaçðes, muitas vezes traz coros puramente animais. Fechando um ciclo, temos a matança na tragédia e o esforço para reverter os maus fluidos através da ressurreição que se dá no drama satírico e na comédia.

As figuras 8 e 9 são de um mesmo tipo, mostram animais montados por guerreiros. No skiphós ático do início do séc. V, delfins dançam ao som da flauta. Na ânfora ática do séc. VI, cavalos e seus cavaleiros executam uma coreografia. Nesse vaso, freqüentemente associado à comédia Os Cavaleiros de Aristófanes, embora seja cem anos anterior àquela, é visível o disfarce. Os homens que se fazem de cavalos usam uma malha à qual se prende o rabo e uma espécie de chapéu na forma da cabeça do animal, mas que deixa à vista o rosto do dançarino. No caso dos delfins, o realismo da representação é menor e não revela os segredos da caracterização.

A partir da descrição acima é evidente que dessa vez estamos fazendo o caminho oposto. A presença do flautista em ambas as cenas e a minúcia no registro da idumentária, indicam que os vasos retratam coros, provavelmente de ditirambos, e não mais kômoi, como os anteriores. Ao deixarmos o âmbito do kômos e entrarmos no do coro, é hora de tecermos algumas consideraçðes sobre essa passagem.

Essa pesquisa, orientada pela representação figurada na arte cerâmica, permite que comprovemos a função cultual do kômos, implicada na definição proposta no início desse artigo. Tanto o kômos mitológico quanto o de disfarce animal representam apenas aspectos do culto, uma vez que seus integrantes ou são acompanhantes e fiéis de algum deus (Mênades e Dioniso, Ninfas e Ârtemis), ou estão relacionados diretamente ao ritual de sacrifício (kômoi animais).

Não podemos perder de vista que as representaçðes teatrais são antes de tudo festivais religiosos. Embora o coro deva se adaptar às necessidades dramáticas, assumindo outras funçðes que a cultual (confidente e conselheiro dos protagonistas, comentador para o público, etc.), cabe a ele a celebração dos deuses através de hinos. Ele, que faz a ligação entre atores e espectadores, ao circular pela orquestra, também é o intermediário entre homens e deuses, e por isso é quem melhor conhece a natureza divina, que procura traduzir em seus cantos. Assim, o coro é o herdeiro dos $k \hat{o m o i} i^{3}$.

\section{Notas}

1- Uma das características imagéticas de Dioniso, o deus-máscara, é a frontalidade de sua representação, quando convencionalmente os deuses são retratados de perfil. Seria esse Sátiro uma metamorfose do deus? $C f$. Vernant. Figuras da máscara na Grécia antiga. In: VERNANT \& VIDAL-NAQUET. Mito e tragédia na Grécia Antiga. Tradução de Bertha Gurovitz. São Paulo: Brasiliense, 1991, p.42. 
2- Exemplo disso são os Sátiros com pés ou orelhas humanas que aparecem numa enorme quantidade de vasos do séc. V. Tal mudança na representação poderia indicar que o drama satírico teria sido o modelo de tais cenas e que o artista teria retratado atores disfarçados e não seres mitológicos.

3- Uma primeira versão desse artigo foi apresentada à $\operatorname{Prof}^{\mathrm{a}} \mathrm{D} \mathrm{r}^{\mathrm{a}}$ Haiganuch Sarian como trabalho de conclusão do curso Teoria da Imagem e Iconografia do Mito e da Religião na Antigüidade Clássica, oferecido durante o $1^{\circ}$ semestre de 1994 na FFLCH/USP.

\section{Referências Bibliográficas}

ADRADOS, F. R. Fiesta, comedia y tragedia. Madrid: Alianza Editorial, 1983.

BOARDMAN, J. Athenian black figure vases. London: Thames \& Hudson, 1985 (*1974).

BURKERT, W. Greek religion. Oxford: Basil Blackwell, $1990(* 1977)$.

CARPENTER, T. M. Dyonisian imagery in archaic greek art (Its development in black-figure vase painting). Oxford: Clarendon Press, 1990 (*1986).

CARTLEDGE, P. The greeks religious festivals. In: EASTERLING, P. E.; MUIR, J. V.. Greek religion and society. Cambridge: University Press, 1992, p.92-127.

GHIRON-BISTAGNE, P. Komos et kômoi: recherches sur l'origine des acteurs et des genres scéniques. In: _. Recherches sur les acteurs dans la Grèce antique. Paris: Les Belles Lettres, 1976, p.207-297.

JEANMAIRE, H. Le thiase et l'origine du théâtre. In: _.. Dionysos. Histoire du culte de Bacchus. Paris: Payot, $1985\left({ }^{*} 1951\right)$.

LEACH, E. Aspectos antropológicos da linguagem: categorias animais e insulto verbal. Tradução por Letícia Maria Antoniolli e Roberto Da Matta. In: DA MATTA, R. Edmund Leach. São Paulo: Ática, 1983, p.170-198.

SIFAKIS, G. M. Parabasis and animal choruses (A contribution to the history of attic comedy). London: The Athlone Press, 1971.

DUARTE, Adriane da S. La préhistoire du choeur théâtral dans l'iconographie du kômos. Classica, São Paulo, 7/8: 219-228, 1994/1995.

RÉSUMÉ: Á travers l'iconographie du kômos, il est possible de remonter à l'origine du choeur grec, élément central et caractéristique du théâtre classique. En partant de la définition: "le kômos est un groupe qui se déplace pour réaliser une action cultuelle, avec procession et danse", on va examiner trois aspects de sa représentation dans l'art céramique: l'aspect mythologique, le cultuel et l'animal. MOTS CLÉS: Théâtre grec, Choeur dramatique, Iconographie du kômos, Religion grecque, Dyonisos. 


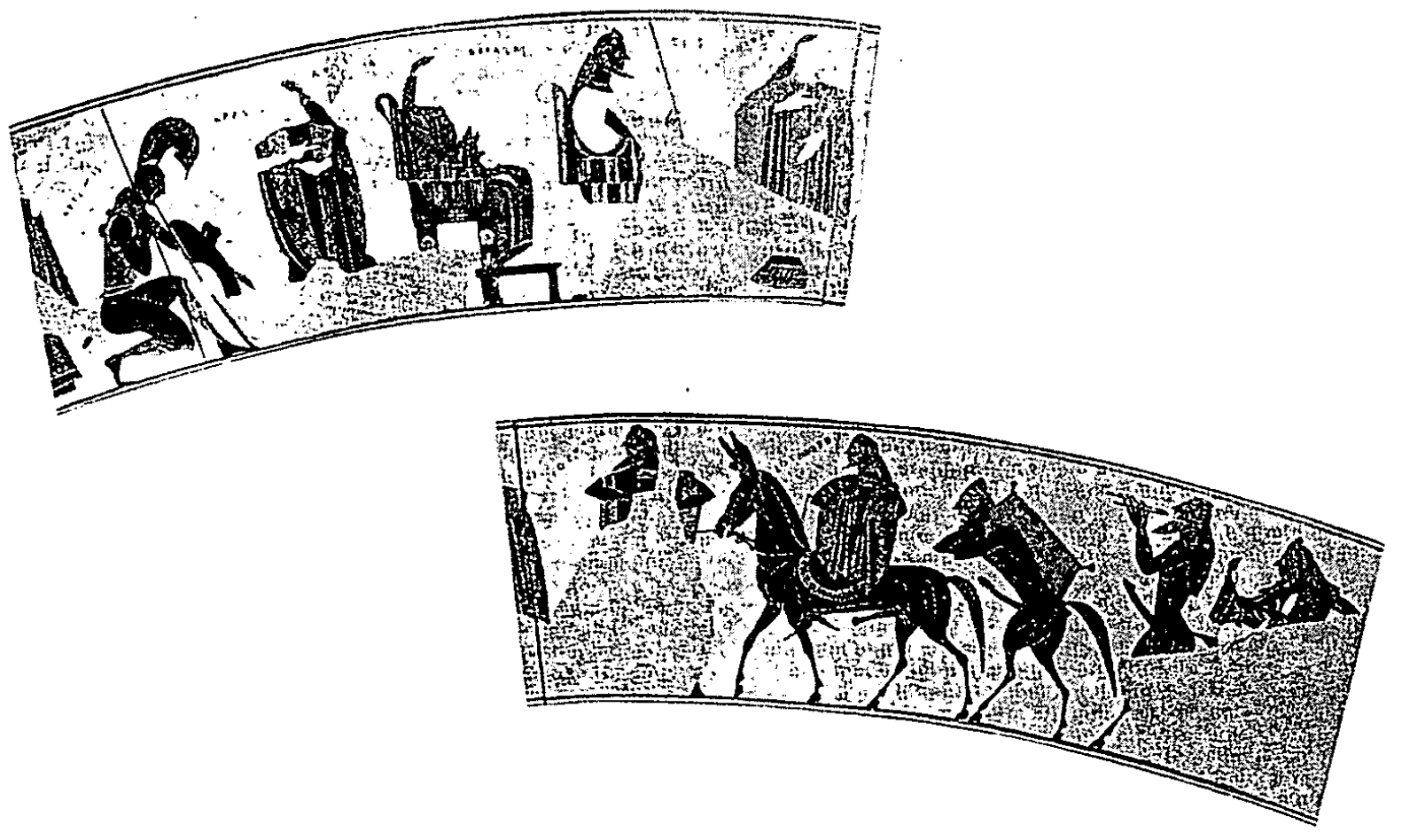

Figura 1
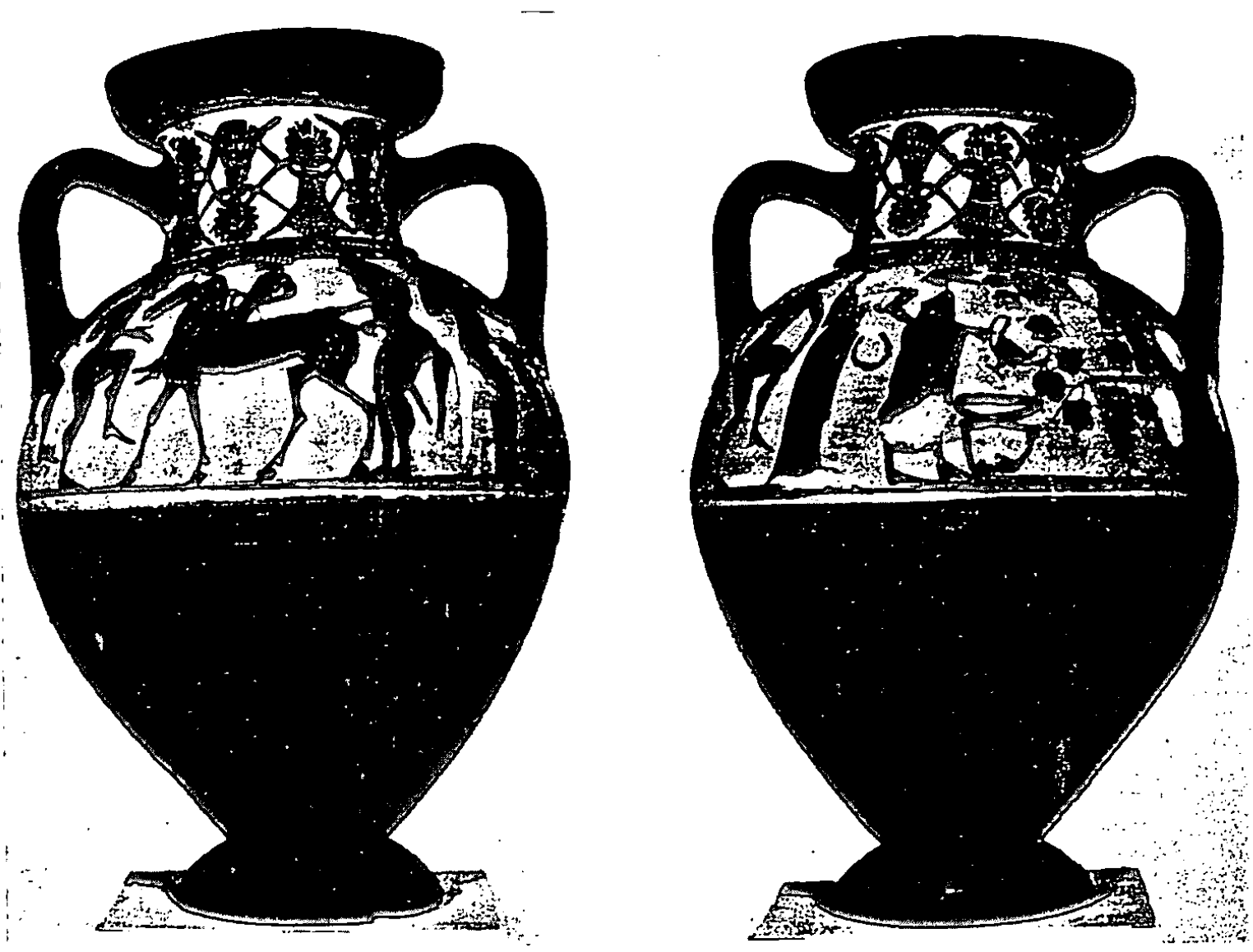

Figura 2 


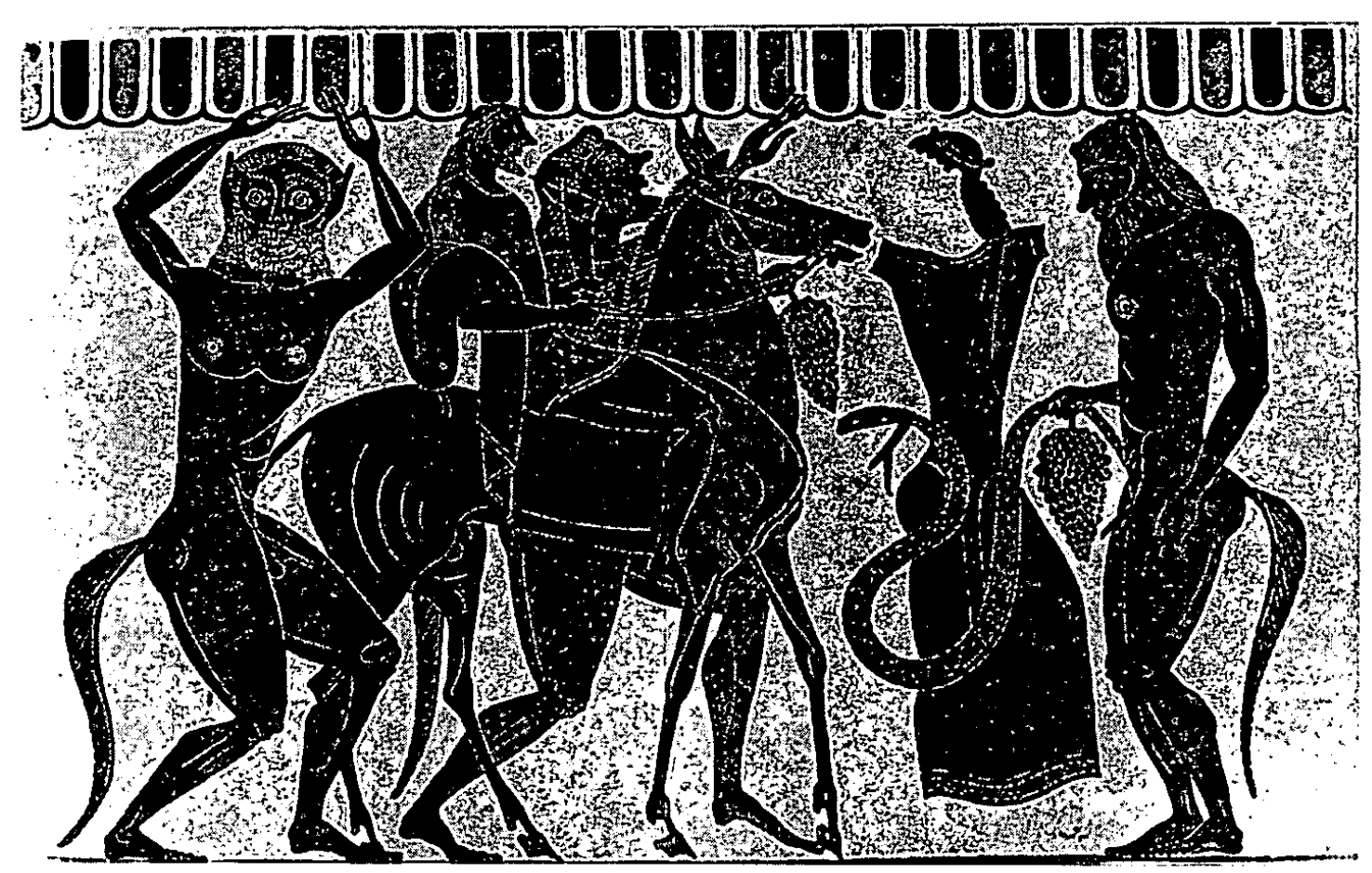

Figura 3

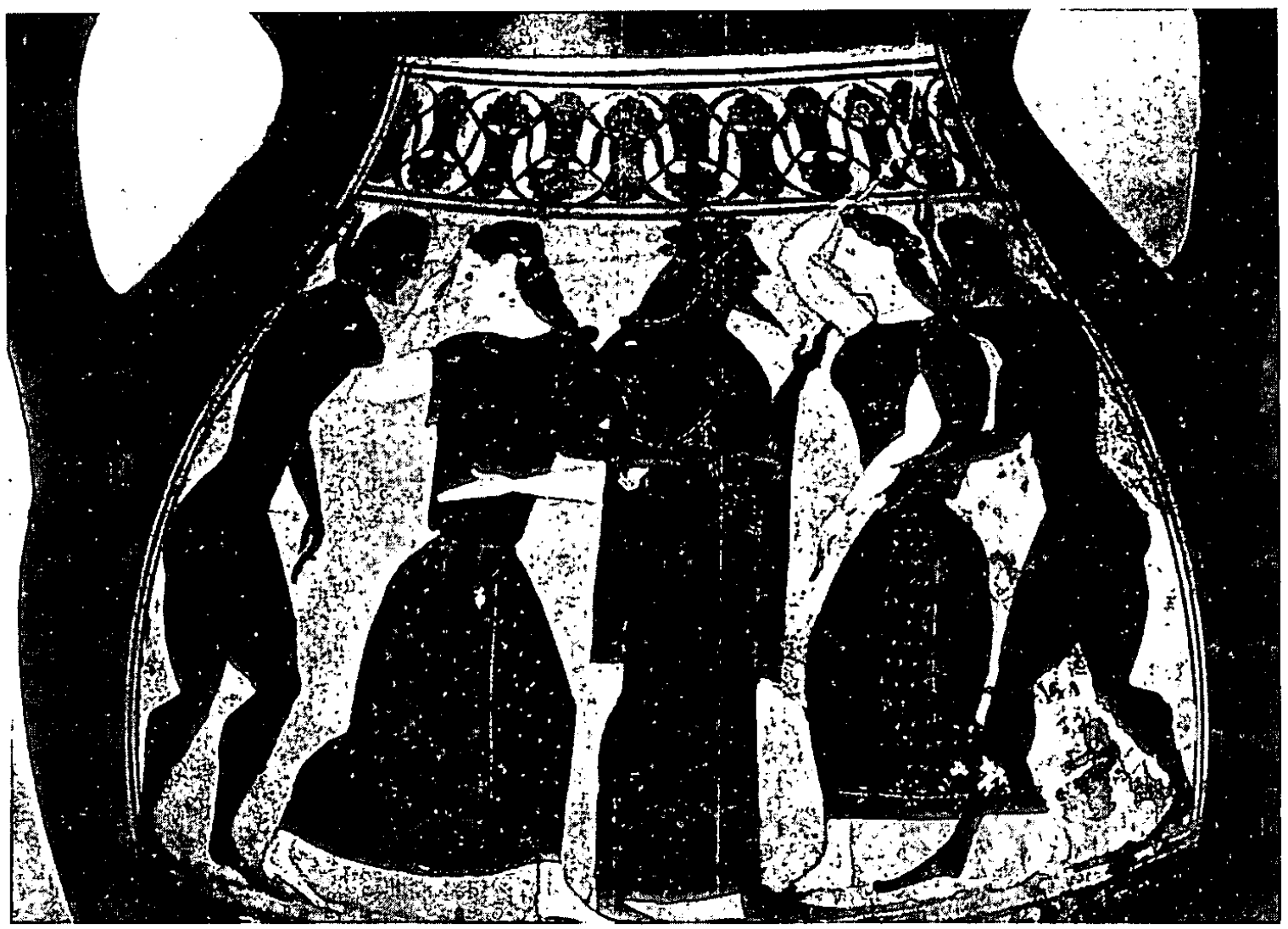


Classica, São Paulo, 7/8: 219-228, 1994/1995

227

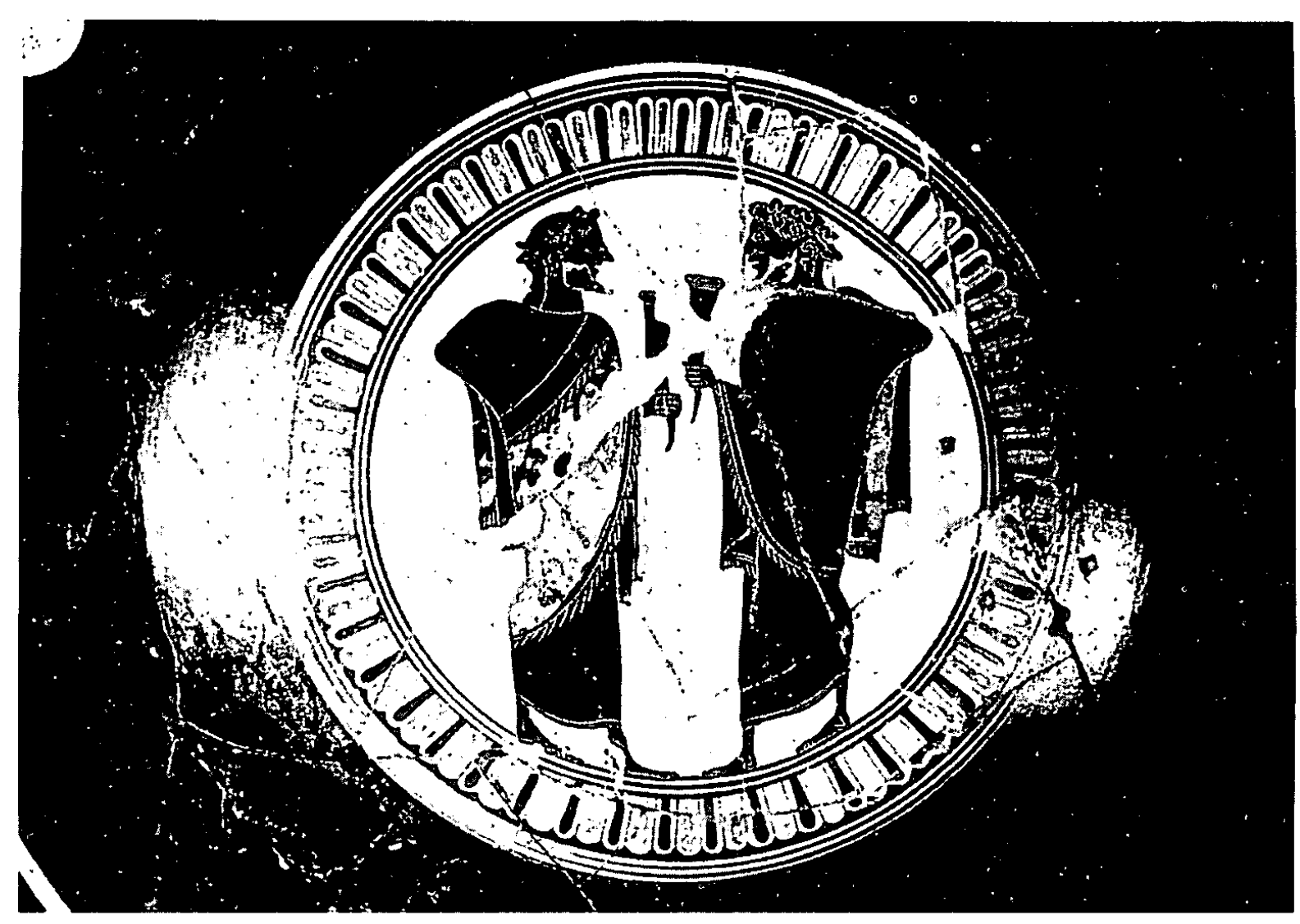

Figura 5

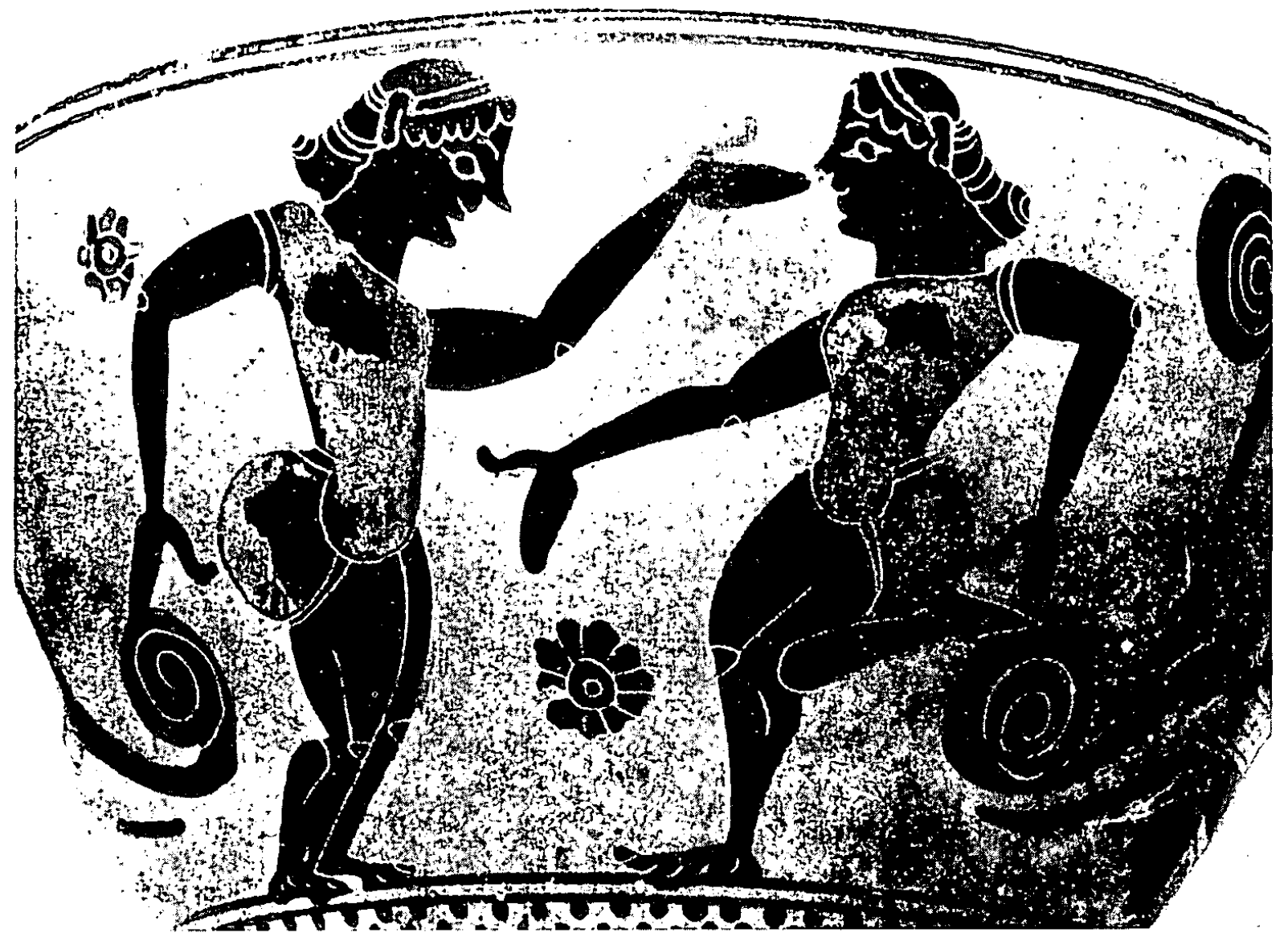

Figura 6 

iconografia do kômos.

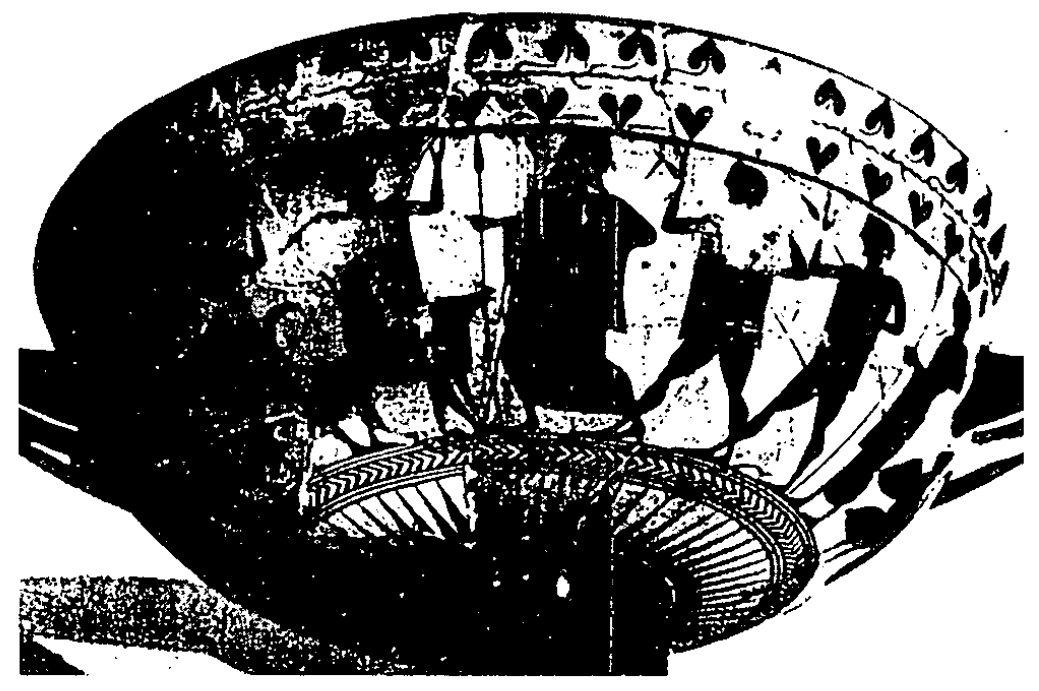

Figura 7

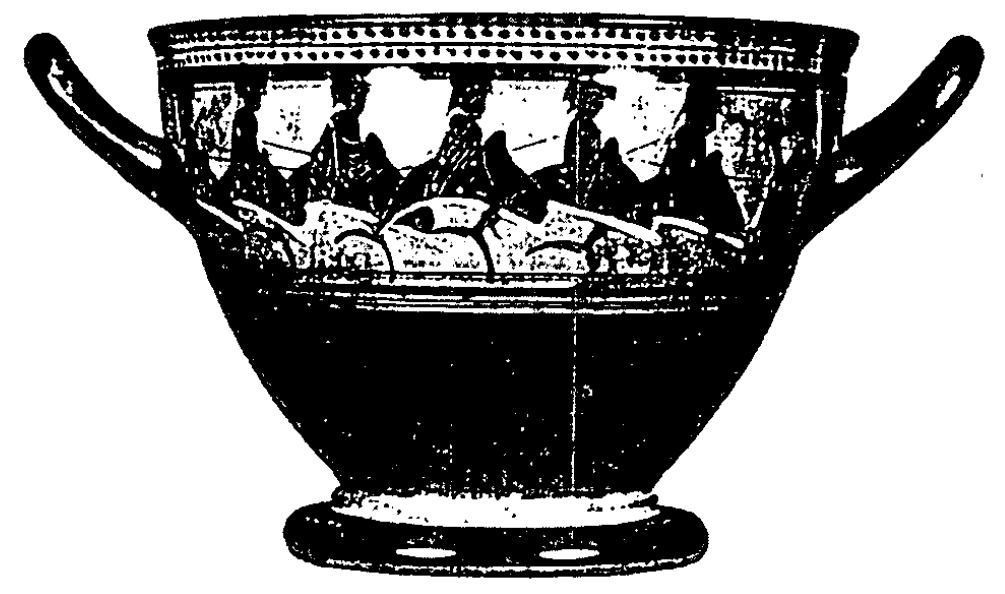

Figura 8

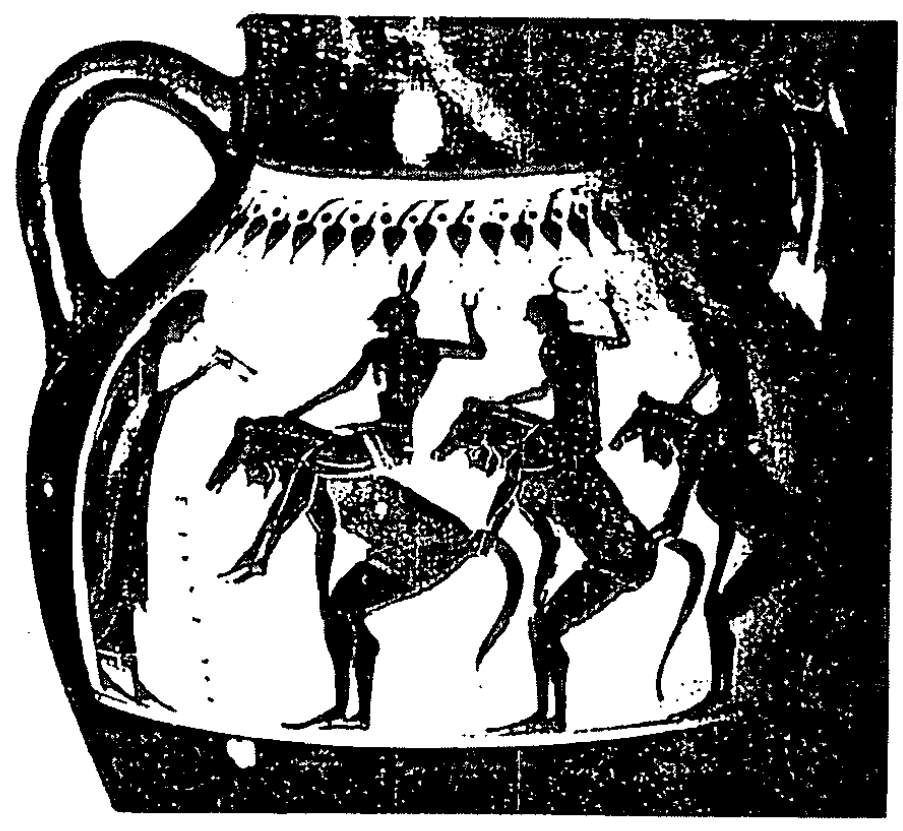

Figura 9 